\title{
Integration of TED-Ed Lessons and TED and TEDx Talks to Enhance College Classroom Instruction
}

\section{Lepervanche Valencia, Jose G.}

School of Business, Florida State College at Jacksonville, USA

\begin{abstract}
Florida State College at Jacksonville (FSCJ) obtained a TEDx license to offer educational events and additional learning resources to enhance college classroom instruction. TEDXFSCJ has organized annual conferences and salons with selected faculty, graduates, and students as speakers. This work presents how TEDxFSCJ Talks and other TEDx and TED Talks have been used to create innovative TED Ed Lessons as tools to expand learning beyond course content and textbooks. Innovative learning experiences include video discussions and roundtables, workshops for faculty to learn how to create TED Ed Lessons, workshops and mentoring to TEDXFSCJ speakers to create their own TED Ed Lessons, combined online discussions in different courses using TED Ed platform, interactive TEDXFSCJ Salons, simulcasts, Learning Adventures, and integration of all TED resources in blogs and Learning Management Systems. TEDxFSCJ Learning Adventures have been used in Management courses during academic year to plan and deliver team projects using selected talks related to leadership, social responsibility and Sustainable Development Goals. Results show that new TED Ed Lessons can be created to follow up engagement. Additionally, team projects in other disciplines can be developed using this innovative methodology. TED resources offer global learning opportunities to build engagement.
\end{abstract}

Keywords: TEDEdLessons; TEDTalks; TED; TEDx; TEDXFSCJ; GLOBE. 


\section{Introduction}

Florida State College at Jacksonville (FSCJ) is a community college that serves workforce educational need of Northeast Florida, USA. The mission of FSCJ (www.fscj.edu) is to provide high value, relevant life-long education that enhances the intellectual, social, cultural and economic development of our diverse community. One of the resources used to enhance college courses has been TED Ed Lessons and TED and TEDx Talks.

TED (www.ted.com) is a nonprofit devoted to spreading ideas, usually in the form of short, powerful talks (18 minutes or less). Independently run TEDx events help share ideas in communities around the world (TED, 2018). "TED began as annual conference, bringing together the fields of technology, entertainment, and design (hence the name). But in recent years it has expanded to cover any topic of public interest" (Anderson, 2016). TED has also "tapped into the collective wisdom of thousands of self-organized TEDx events" (Anderson, 2016). In TEDx, local organizers apply for a free license to run a local TED-like event. TEDxFSCJ licensed founder and organizer is a Professor of Florida State College at Jacksonville. TEDxFSCJ main events, salons, and simulcasts are planned by a team of professors, staff, and students. Students have a TEDxFSCJ Club and a professor as club's advisor.

This work includes all the educational events and learning experiences done in TEDxFSCJ events, faculty workshops and courses in the Bachelor of Applied Science in Supervision and Management. The objective is to share how TED resources have been used to find global learning opportunities building engagement inside and outside the classroom. All different learning experiences are explained with a call to action to fellow professor to use these resources in other disciplines. One of the results of these global experiences was the creation of an educational model to facilitate implementation. A global learning model was used to integrate TEDxFSCJ into Learning Management Systems to enhance online and hybrid instruction.

\section{TEDxFSCJ: Life Lessons Beyond the Learning Edge}

TEDxFSCJ brought the spirit of TED's mission of ideas worth spreading to Florida State College at Jacksonville. Life lessons beyond the learning edge was our first and continuous theme. According to TED (www.ted.com), independent TEDx events are operated under license from TED. In the spirit of ideas worth spreading, TED has created a program called TEDx. TEDx is a program of local, self-organized events that bring people together to share a TED-like experience. FSCJ main event is called TEDxFSCJ conference, where $\mathrm{x}=$ independently organized TED event. At TEDxFSCJ event, TED Talks videos and live speakers are combined to spark deep discussion and connection to FSCJ students and local 
community. The TED Conference provides general guidance for the TEDx program, but individual TEDx events are self-organized (www.tedx.com).

\section{TEDxFSCJ Conference, Salons, and TED Simulcasts}

The initial concept of TEDxFSCJ was to invite selected faculty, graduates, and students to speak about their "life lessons beyond the learning edge" understanding this edge as college graduation or learning beyond courses or terms. From the beginning in 2013, TEDxFSCJ has been looking for ideas that are being generated outside the classroom that are serving to expand education to homes, workplaces, and the community.

TEDxFSCJ has used the yearly main conferences, TEDxFSCJ Salons, TED Live and Women simulcasts, TED Ed Lessons, TED Knowledge Workshops, and integration of TED Ed Lessons, and TED and TEDx Talks to educational blogs and Learning Management Systems (LMS) such as Blackboard. All TED resources have been used in face-to-face and online college courses. TEDxFSCJ main conferences and themes were: "Life Lessons Beyond the Learning Edge (2014), "Brave New World" (2015), "Engage" (2016), and "Barriers" (2018).

\section{TED Knowledge Workshops}

Workshops were created, planned and delivered in several FSCJ campuses. "TED Knowledge Workshop: How to Create TED Ed Lessons" is the learning opportunity use to teach professors to embed TED and TEDx Talks in Blackboard online courses and to create your own TED Ed lessons. A recorded video "TED Knowledge Workshop" (Lepervanche, 2016) was added to bring workshop's content to online professors.

The initial workshop's presentation encouraged the use of TED resources to show to faculty members how these resources could be integrated to college courses (Lepervanche, 2014). After creating relevant TED Ed Lessons and combined discussions, they were added to Blackboard and later to blogs. Learning blogs posts were organized in global categories by activities, topics, SDGs, and countries. Workshops demonstrated how to create TED Ed Lessons using relevant TED Talks and, it showed how to integrate or embed these resources into LMS of Management Courses in order to enhance classrooms, online discussions, and outdoors learning experiences. 


\section{TED Ed Lessons in College Education}

To date the author has created, shared, and used more than 50 TED Ed Lessons for college instruction. Lessons have been created using own and TED and TEDx videos. Some of the lessons include TEDxFSCJ speakers. "Risk-taking, mistake-making, and lifelong learning" was the talk by TEDxFSCJ speaker Dr. Kathleen Ciez-Volz that was used to create a TED Ed Lesson (https://ed.ted.com/on/cTIQI79M). This lesson has been used in Management courses and has more than 25,000 views, including combined Blackboard and TED Ed online discussions.

Lessons include topics in Leadership, Online Learning, Robotics, Business, Space, Information Technology, Social Responsibility, Science, Scouting, Energy and more. A lesson about combined on-ground and online discussions outside specific LMS was created to illustrate these concepts to students and other professors. "Management Learning Online Laboratory: TECHknowledge: Technology \& Knowledge" was instrumental to Management and Business students to understand and apply device oriented learning with TED Ed lessons to expand online and offline discussions to different management courses. Students from one course used TED Ed discussion to exchange comments with students from other courses expanding the learning experience beyond the classroom (https://ed.ted.com/on/s641YS1j).

One of the takeouts of a TED Talk is to "include a clear and compelling call to action in the closing of the speech" (Karia, 2012). The idea is to tell the audience what need to be done to close the gap to make the idea a reality. Asking TEDxFSCJ speakers to create their own lesson was the way to bring their ideas to action in their classrooms and beyond. For example, TEDxFSCJ speaker Dr. Dianne Fair talked about the "The Fight Against Microorganisms" and she later created her own TED Ed lesson (https://ed.ted.com/on/od0MVioT).

\section{Adventure Catalysts in TEDxBeaconStreet, TED Active and international TEDx events}

The creation of TED Ed lessons for higher education and TEDxFSCJ Learning Adventures were inspired by the "Ideas to Action" powerphrase used in TEDxBeaconStreet' Adventures (TEDxBeaconStreet, 2014). According to Reissman (2014) TEDxBeaconStreet team has created a template for any TEDx organizer to use to host their own Adventure, offering a toolkit and ample advice. TEDxFSCJ Organizer was invited to be one of Adventure Catalysts to meet with TEDx speakers and other innovators. The objective was to learn how to follow the ideas after the talks to see the results of calls to actions. These 
follow up ideas were later used to shape TEDxFSCJ Learning Adventures and to formulate a global learning model to bring international TED learning experiences to classrooms.

TED Active 2015 in Whistler, Canada and TEDx events in Czech Republic (TEDxPrague), and Spain (TEDxCibeles, TEDxUPValencia, and TEDxAlcoi) plus TEDxCommunity blog were added as examples of global learning opportunities. TEDxJacksonville, TEDxOcala and TEDxUF were used as examples of local and regional learning opportunities. It is important to note that TEDxUPValencia is organized by the Polytechnic University of Valencia and TEDxUF by the University of Florida. These are a couple of examples of TEDx licenses organized by higher education institutions.

\section{Global Learning Opportunities Building Engagement and TED}

After the learning experience with TED Ed Lessons, TED Active and international TEDx events, a collaborative educational model was developed to facilitate the use of TED resources plus other similar global learning initiatives that use innovative instructional ideas. The Global Learning Opportunities Building Engagement (GLOBE) model created by Lepervanche (2016) has been used in Business, Management, and Systems courses and can be used in any global learning area, program, or course. The GLOBE model was presented during the Global Education Conference (2017) (www.globaleducationconference.com). The objective of GLOBE is to: 1. Find Global Learning Opportunities. 2. Building bridges by connecting speakers with Management courses. 3. Build Engagement by creating active and continuous collaboration. GLOBE educational model facilitates global collaboration and creative learning methods inside and outside the classroom to enhance Management programs (Lepervanche, 2016).

In order to expand these learning experiences beyond TED, several blogs were developed to use other non-TED videos and educational resources. Free Campus (https://freecampusdotorg.wordpress.com) includes TED Ed Lessons, TED and TEDx Talks, and other instructional videos. Outdoors University (www.outdoorsuniversity.com) uses GLOBE to focus on outdoors learning. All current blogs posts, and TED Ed Lessons are free and available to use.

\section{Integration of TED Ed Lessons in Blogs to Enhance Management Courses}

Blogs have been used in online education to bring current topics to Management courses. The use of blogs enhance analysis of current events that impact companies. This is an innovative way to enhance online classrooms. "As traditional classroom is changing nationwide and future careers are dependent on strong computer skills, blogging helps your 
students develop necessary skills for their continuing education and gainful employment." (Pappas, 2013).

TED Talks also provide a way to provide deep discussions and extra engagement to online classrooms. Topics range from online education, technology management and data-driven business to enhance online engagement in discussions and assignments. "Each keystroke, quiz, peer-to-peer discussion and self-graded assignment builds an unprecedented pool of data on how knowledge is processed." (Koller, 2012).

\section{Integration of Global Outdoors Learning Blogs, TED Ed Lessons and Global Goals in Management Courses}

During academic year 2017-18 integration of TED Ed Lessons and Global Outdoors Learning Blogs was expanded to include UN Sustainable Development Goals (SDGs) to be added to topics in Management courses. Blogs posts and TED Ed Lessons were integrated to LMS using the GLOBE model. The SDGs, otherwise known as the Global Goals, are "a universal call to action to end poverty, protect the planet and ensure that all people enjoy peace and prosperity" (UNDP, 2015).

The objective was to find Global Learning Opportunities that were useful to our courses or programs. Building bridges included connecting speakers, presenters, adventurers, travelers, facilitators or influencers with Management courses (Global Management, Outdoors Leadership, Youth Leadership, City Management, Strategic Management, Technology Management). Engagement was done by creating active and continuous collaboration using blogs posts and adding TED Ed lessons with TED talks related to specific Management topics and SDGs. Integration of resources to LMS allowed students to be prepared to plan TEDxFSCJ Learning Adventures.

\section{TEDxFSCJ Learning Adventures}

TEDxFSCJ Learning Adventures were developed following the Adventures model suggested by TEDx Beacon Street "An innovation to extend the TEDx phenomenon beyond a single-day conference format and offer a platform for the community to interface with speakers and innovators throughout the year." (TEDxBeaconStreet, 2014). The idea of TEDxFSCJ Learning Adventures was to share and to discuss updated topics and lessons using TED and TEDx Talks, with emphasis in the use of TEDxFSCJ Talks. 
During 2017-18 FSCJ academic year TEDxFSCJ Leading Adventures were incorporated to team projects in Global Management, International Business, and Global Leadership courses. Students from different courses in the same term used GLOBE educational model to pre-select 10 TED or TEDx Talks related to Leadership, Social Responsibility, and the SDGs. An animated video and flowchart were produced to visualize the steps of the team project "Leadership, Social Responsibility, and Sustainable Development Goals" (Lepervanche, 2017).

GLOBE model integrated United Nations' SDGs with TED Talks related to Leadership and Social Responsibility. Students selected TED videos, defended their pre-selections during class and voted for the top three, and produced an individual report about speaker contributions to one or more SDGs. Teams selected one video to produce a TEDxFSCJ Learning Adventures' presentation for a final roundtable. An event scheduled to host the roundtable and discuss about the selected videos. Presenters shared how the videos related to leadership and corporate social responsibility. They also had to explain how the ideas presented are contributing with one or more of the 17 SDGs. The results of roundtables were useful to create TED-Ed Lessons to be used for upcoming online combined discussions. This GLOBE project idea can be used for future courses in other disciplines including new TED Talks and different SDGs. Similar project was done by online students in the same term. Roundtables were conducted online in a discussion forum. Enhancement and engagement, not only occurred in present term, but a new TED Ed was created to produce additional enhancement and engagement in next term course.

\section{Results and Conclusion}

This work presented how TEDxFSCJ Talks and other TEDx and TED Talks have been used to create innovative TED Ed Lessons as tools to expand learning beyond course content and textbooks. It showed how using a global learning model such as GLOBE, innovative learning initiatives can be integrated to face-to-face and online courses. Integrated tools allowed to expand and enhance higher education courses beyond course content and textbooks. Tools allow to explore online platforms outside LMS to do combined online discussions or to continue discussion after a course or term is over. New TED Ed Lessons can be created based on conclusions of selected talks and/or roundtables. A survey using the Technology Acceptance Model (Davis, 1989) was delivered to FSCJ students who participated in TEDxFSCJ Learning Adventures. Preliminary results shows acceptance of these resources in terms of usefulness and ease to use. A complete quantitative analysis is planned for future academic year.

TED and TEDx events, salons, TED Ed Lessons, workshops, and presentations are available worldwide to enhance learning engagement in courses and outside the classroom. 
These are the recommendations: 1. Incorporate TED and TEDx Talks to courses and to generate post-videos discussions. 2. TEDx events are scheduled in many cities and countries. Invite speakers to be course's guest lecturers or to create TED Ed lessons. 3. Add TED Ed lessons to generate discussions outside the courses. 4. Follow ideas and actions of TEDx speakers and see how their actions benefit their communities, workplaces, or the environment. 5. Join a local TEDxCommunity and be a Learning Adventures catalyst.

\section{References}

Anderson, C. (2016). TED Talks. The Official TED Guide to Public Speaking. New York, USA: Houghton Mifflin Harcourt Publishing Company.

Davis, F. D. 1989. Perceived usefulness, perceived ease of use, and user acceptance of information technology. MIS Quart. 13 319-339.

Karia, A. (2012). How To Deliver a Great TED Talk. Lexington: Akash Karia.

Koller, D. (2012). "What we're learning from online education". TED Global 2012. $\begin{array}{lllll}\text { Retrieved on } & \text { December } & 2017 & \text { from }\end{array}$ https://www.ted.com/talks/daphne_koller_what_we_re_learning_from_online_education

Lepervanche, J. (2014). TED-Ed, TED and TEDx Talks to Enhance Classroom Learning Experience. Retrieved from https://www.slideshare.net/jlepervanche/teded-ted-and-tedxtaks-to-enhance-classroom-learning-experience-dr-jose-g-lepervanche

Lepervanche, J. (2016). "Global Learning Opportunities Building Engagement (GLOBE)." $\begin{array}{lllll}\text { Retrieved on } & \text { December } & 22, & \text { from }\end{array}$ https://lepervanchelearning.wordpress.com/2016/09/26

Lepervanche, J. (2017, September 7). Leadership, Social Responsibility, and Sustainable Development Goals [Web log post]. Retrieved from https://lepervanchelearning.wordpress.com/2017/09/07/tedxfscjlearningadventures_lead ership

Lepervanche, J. (2018, February 8). TED Ed Lessons used in Management courses [Web $\log$ post]. Retrieved from

https://lepervanchelearning.wordpress.com/2017/09/06/ted-ed-lessons-used-inmanagement-courses-dr-jose-g-lepervanche-tedxfscj

Pappas, C. (2013). "How To Use Blogs In the Classroom. Elearning Industry." Retrieved on December 21, 2017 from https://elearningindustry.com/how-to-use-blogs-in-theclassroom 
Reissman, H. (2014, July 15). Fun and nerdy field trips: TEDx Adventures take to the streets [Web log post]. Retrieved from https://blog.ted.com/fun-and-nerdy-field-tripstedx-adventures-take-to-the-streets

TED (2018). Our Organization. Retrieved from https://www.ted.com/about/ourorganization

TEDxBeaconStreet (2014). What Are Adventures? Retrieved from http://www.tedxbeaconstreet.com/adventures-list

United Nations Development Programme (UNDP) (2015). Sustainable Development Goals. Retrieved from http://www.undp.org/content/undp/en/home/sustainable-developmentgoals.html 